\title{
Milk and Its Products: Effect on Salivary pH
}

\section{ALPNA SHARMA ${ }^{1}$, DHEERAJ SHARMA², SIMARJEEV SINGH³, ADITI SHARMA4, ROHINI SHARMA5, MANU SHARMA}

BACKGROUND: Dairy products are perceived to be important for one's overall and dental health. Dairy products have been identified as having anticariogenic activity due to the high content of calcium and phosphorous ions and casein phosphopeptides.

AIM: To determine the $\mathrm{pH}$ levels of human saliva after consuming different dairy products.

DESIGN: sixty students were divided into 2 groups ( 30 with caries and 30 caries free) aged 5-9 years, visited to department of paedodontics and preventive dentistry, who agreed to refrain from oral hygiene procedures for 24 hours were selected for this study. Both groups were further randomly sub-divided into 3 groups (milk, curd and paneer group). After determining baseline salivary $\mathrm{pH}$ using a digital $\mathrm{pH}$ meter, the subjects were asked to eat the test foods (milk $50 \mathrm{ml}$, curd $50 \mathrm{~g}$ and paneer $50 \mathrm{~g}$ ) and salivary $\mathrm{pH}$ was measured at time intervals of $1,5,15$ and 30 minutes. RESULTS AND CONCLUSION: The results were statistically measured by using ANOVA test for intergroup and intragroup comparison. Significant decrease in $\mathrm{pH}$ was observed at various time intervals and more decrease was observed in caries active group.

KEYWORDS: Salivary pH, Milk, Curd, Paneer

\section{INTRODUCTION}

Dental caries is a major dental public health problem and is the most prevalent oral disease among lower age group across the world. It is estimated that around $95 \%$ of the world's population is affected by dental caries. ${ }^{1}$ In India, $23 \%$ of 12 year olds suffer from this condition. ${ }^{2}$ The role of nature of saliva as an etiological factor behind dental caries cannot be denied. The mechanism of salivary role has been the aim of study by countless investigators, either for direct reasons or because of suspected causal relationship with tooth decay. The properties and functions of saliva, as well as role of saliva in oral health have been discussed extensively in textbooks and numerous publications. ${ }^{3}$

"Good oral health comes from good food" - this concept has given to a tremendous increase in the consumption of milk and milk derivatives. Commonly available drinks/beverages are known to lead to a significant dip in the salivary $\mathrm{pH}$ due to the presence of sugars and organic acids. In the literature pertaining to dental health, this drop point is reported to be the critical $\mathrm{pH}$ of salivary fluid, the value of which is 5.5 (Stephan, Englander et al and Schmidt-Nielson, 1946). A further fall in $\mathrm{pH}$ disturbs the calcium and phosphate regulatory balance at which dental caries becomes inevitable. ${ }^{4}$

The nature of milk and related products has been thoroughly argued. They are known to have a low cariogenic potential, but their Cariostatic behavior has also been reported (Johansson, 2002). ${ }^{5}$ Research data till date has demonstrated that milk and related products such as yogurt, curd and cheese are beneficial to the health of hard dental tissues. ${ }^{6}$ The caries stabilizing effect of milk and derived products is probably due to the buffering capacity generated from the high content of Calcium and Phosphate ions and the presence of casein phosphopeptides. ${ }^{7}$

One of the objective of dental research has been to identify the factors in food that can protect teeth against caries. Two major advantages of protective agents found in milk and milk products are that a) It would be perceived as a natural product and b) Milk is recommended on account of its nutritional properties, chiefly as a source of calcium and protein and accordingly its use does not raise any toxicological problems. $^{6}$

Drop in the salivary pH after any dietary intake is a determining parameter for oral health. With all this on mind, the following study was proposed to be conducted to ascertain the disparity in $\mathrm{pH}$ of whole saliva, following the intake of milk and milk derivatives.

The aim of the present study was to determine the $\mathrm{pH}$ levels of human saliva after consuming different dairy products.

\section{MATERIALS AND METHOD}

The approval was obtained from Ethical Committee, Swami Devi Dyal Hospital and Dental College, Barwala, Panchukula, Haryana. The study was carried 
out among 6o voluntary subjects (30 with caries and 30 caries free) with the age group 5-9 years and were screened using following inclusion criteria:

\section{Inclusion Criteria:}

i) Child should be 5-9 years of age.

ii) Without any relevant past medical history.

iii) Without any history of antibiotic medication therapy two months prior to the study.

iv) Children with optimum cooperation for the smooth functioning of investigation.

The study subjects were classified as caries free $(\mathrm{CF})$ and caries group (CG). From each group the study subjects were randomly divided into 3 subgroups of milk $(n=10)$, curd $(n=10)$ and paneer $(n=10)$. Details of the study procedure were explained to the subjects and they were asked to abstain from eating and drinking (except plain water) until after that day's dental visit and informed consent was also obtained from each participant.

The digital $\mathrm{pH}$ meter (Max Electronics, India. Model Me 962-P \& Me 963 P) accurate to o.1 was first be calibrated according to the manufacturer's instructions, employing buffer standards of $\mathrm{pH} 7$ and $\mathrm{pH}$ 4. The intrinsic $\mathrm{pH}$ of dairy products was measured by the calibrated digital $\mathrm{pH}$ electrode. $50 \mathrm{ml}$ milk, $50 \mathrm{~g}$ curd and 509 paneer crushed in grinder (all at room temperature) were placed in a beaker and stirred until a stable reading was obtained. An electrode was placed directly into each solution. Between readings, the electrode was rinsed in distilled water to ensure that no cross contamination occurred. Estimation of endogenous $\mathrm{pH}$ of dairy products was done prior to saliva collection.

The salivary $\mathrm{pH}$ was assessed before and after consumption of dairy products (without added sugar). A baseline $\mathrm{pH}$ was measured for all the groups. The subjects were asked to chew one gram of paraffin wax for 3 minutes and saliva samples were collected in glass beakers. The $\mathrm{pH}$ of saliva was recorded as the baseline score by using a standard digital $\mathrm{pH}$ meter.

After the baseline estimation of salivary $\mathrm{pH}$ the subjects were allowed to chew and swish the different dairy products (milk- 50ml, curd- 509 and paneer- 509 ) for 3 minutes followed by swishing their mouth with plain water and the saliva samples of each subject was collected in separate sterile beakers after $1 \mathrm{~min}, 5 \mathrm{~min}$,
$15 \mathrm{~min}$ and $30 \mathrm{~min}$. The collected saliva samples were immediately subjected for estimation of $\mathrm{pH}$ changes using a digital $\mathrm{pH}$ meter. The recordings of the $\mathrm{pH}$ were tabulated and statistical analysis was done.

\section{RESULTS}

Table 1 summarizes data recorded for the three groups analyzed at baseline, 1 minute, 5 minute, 15 minute and 30 minutes. The results showed a statistically significant difference in mean salivary $\mathrm{pH}$ between baseline, 1 minute, 5 minute, 15 minutes and 30 minutes. However, there was a statistically nonsignificant difference in mean salivary $\mathrm{pH}$ between baseline and 30 minutes following consumption of dairy products.

Figure 1 illustrates that the mean salivary $\mathrm{pH}$ in the paneer group rose rapidly after 5 minutes and decreased slightly after 15 and 30 minutes; however the saliva $\mathrm{pH}$ at 30 minute was nearly at baseline. Among those who took milk saliva $\mathrm{pH}$ slightly decreased after 5 minutes and increased again after 15 and 30 minutes. Among the subjects who consumed curd, saliva $\mathrm{pH}$ dropped rapidly after 5 minutes and rose after 15 and 30 minutes. ANOVA one way analysis results showed the saliva $\mathrm{pH}$ at 1 minute, 5 minute and 15 minutes are highly significant but it is non-significant at baseline and 30 minutes.

Table 2 compares caries active and caries free subjects at different time intervals after dairy product consumption. Statistically significant differences were seen between caries-active and caries-free subjects for all the groups at each time interval, all are highly significant except for curd group which is significant at 5 minutes.

\section{DISCUSSION}

Milk derived products have low caries causing potential and signify anticaries activity, although there is a need to conduct additional studies. ${ }^{8}$ The anticaries activity of milk and its products was directly attributable to the chemical effects of casein phosphopeptides, calcium and phosphate ions. ${ }^{6}$ One strategy for evaluating the cariogenic ability of food involves estimating the notability of saliva $\mathrm{pH}$ behaviour following ingestion.

The data compiled in this study revealed the protective nature of dairy products against dental caries. This finding is in line with other write ups unveiling a 
causal relationship between dairy products consumption and reduction of dental caries..$^{9-11}$

Numerous mechanisms by which dairy products can lead to a reduction in enamel demineralization have been advocated. Levine proposed three of these mechanisms. Firstly, milk proteins may get adsorbed onto the surface layer of enamel and may hamper enamel demineralization; secondly, milk fat could adsorb onto the surface layer of enamel and play its safeguarding role; thirdly, enzymes present in the milk enzyme may have a functional role in hindering the proliferation and multiplication of acidogenic plaque bacteria. $^{12}$

Calcium, phosphorus and CPPs are the ingredients in milk derivatives which may exert a shielding effect on the tooth surface. Calcium and phosphorus ions are released from milk products and their concentrations gets increased in the dental plaque, causing inhibition of demineralization and favouring remineralization by common-ion effect. ${ }^{\text {II }}$

The present study uncovered that milk and cheese ingestion led to an escalation in salivary $\mathrm{pH}$, but cheese showed a greater elevation in saliva $\mathrm{pH}$ till 5 minutes, then approached near baseline at 30 minutes whereas the maximum decrease in salivary $\mathrm{pH}$ of milk and yogurt was seen 5 minutes. After 30 minutes, the salivary $\mathrm{pH}$ of the subjects in the milk group was similar to that of the baseline $\mathrm{pH}$, while in yogurt group, it was slightly lower.

After consuming milk products, subjects in cheese group showed highest rise in mean salivary $\mathrm{pH}$. A similar study was performed by Banan LK, Hedge $\mathrm{AM}^{13}$ in 2005 on plaque and salivary $\mathrm{pH}$ changes after consumption of fresh fruit juices and reported that frozen juices lead to a greater dip in Ph of plaque and saliva when compared to refrigerated fruit juices. The effect of cheese in raising plaque $\mathrm{pH}$ has been observed by several investigators (Rugg-Gunn et al. 1975; Silva et al. 1986)..$^{1-15}$ The acidic constituents of cheese (lactic and sorbic acid) may have contributed directly to the subsequent reduction of plaque $\mathrm{pH}$ and also may have depleted the saliva's buffering power. ${ }^{8}$ Minah et al. ${ }^{16}$ in 1986 reported that factors such as salivary $\mathrm{pH}$ rise may favor the competitiveness of less harmless oral bacteria and discourage aciduric bacterial strains such as streptococci and lactobacilli. It can be conjectured that as the $\mathrm{pH}$ rises, less cariogenic bacteria may metabolize the available substrates, producing weaker acids which will help maintain an elevated $\mathrm{pH}$.
Thus, in summary cheese has two mechanisms of protection against enamel demineralization: 1. By releasing calcium and phosphorus and therefore increasing their concentrations in the dental plaque which inhibits demineralization and favours remineralization by a common ion effect. ${ }^{2}$ By stimulating salivary flow and consequently, buffering the dental plaque and exerting a sugar-clearing effect. However milk group also showed a rise in mean saliva $\mathrm{pH}$ levels, but slightly less than cheese group. The decrease in salivary $\mathrm{pH}$ within 5 minutes after consuming milk was similar to a 1985 study by RuggGunn et $\mathrm{al}^{17}$, in which a sucrose solution caused a substantial drop in plaque $\mathrm{pH}$, while milk depressed plaque $\mathrm{pH}$ only slightly. In 2002, Johansson ${ }^{5}$ observed increased acid production due to bacterial enzymes involved in lactose transport and catabolism. The $\mathrm{pH}$ increased slightly after 20 min due to the peptides and amino acids produced by the hydrolysis of casein, which upon further catabolism, can raise the plaque $\mathrm{pH}$ and prevent demineralization. This process of alkaline production may counteract the acid production from lactose fermentation. ${ }^{5}$

The curd consumption in this study led to a rapid drop in the salivary $\mathrm{pH}$, the decrease drive it near critical $\mathrm{pH}$ of 5.5 at 5 minutes similar to results of a 2007 study by Sonmez and Arasi. ${ }^{18}$ The initial fall in plaque $\mathrm{pH}$ was due to acidic nature of the yogurt $(4.0-4.5 \mathrm{pH})$. The increase in $\mathrm{pH}$ after 15 and 30 minutes may be due to the buffering capacity of stimulated saliva, and the reduced lactose content of the yogurt due to fermentation. The increase in $\mathrm{pH}$ may also be due to the fact that the natural CPP content present in yogurt is higher than that of milk due to proteolytic activity of microorganism contained in yogurt and the peptides and amino acids produced by hydrolysis of casein. Both of these have a potential to produce a $\mathrm{pH}$ rise in plaque upon further catabolism and prevent demineralization. ${ }^{5,18}$

The curd group also showed a rise in mean saliva $\mathrm{pH}$ but slightly less than for cheese group. The results of our study are similar to those of Ferranzzano et al. ${ }^{7}$ in 2008. It has been hypothesized that bacteria present in yogurt may have a positive influence on the ecology of dental plaque, re-establishing the microbial hemostasis broken down by the bacterial metabolism. Recent studies reported that yogurt and probiotic containing milk and cheese consumption has been positively related with a decrease in streptococcus mutans in dental plaque and/or saliva (Nikawa et al., 2004; Caglar et al., 2005). ${ }^{19-20}$ This hypothesis could 
represent a favorable outcome in terms of prevention of dental caries.

\section{CONCLUSION}

Among the 3 dairy products consumed, paneer showed the most appreciable salivary $\mathrm{pH} 5$ minutes after consumption followed by milk and curd, then reached baseline at $30 \mathrm{~min}$. This suggests that cheese has the top most anti-cariogenic property among these dairy products. Curd in this study lessened the salivary $\mathrm{pH}$ to critical $\mathrm{pH}$ of 5.5 at $5 \mathrm{~min}$, below that enamel demineralization and dissolution are anticipated, but it increased and reached baseline at $30 \mathrm{~min}$. These findings reaffirm that paneer and milk are noncariogenic and to some extent Cariostatic. Milk and milk derived products can be used as surrogate for high-carb desserts and snacks, which may reduce the incidence and prevalence of dental caries.

\section{REFERENCES}

1. Chaudhary SD, Chaudhary M, Singh A, Kunte S. An assessment of cariogenicity of commonly used infant milk formulae using microbiological and biochemical methods. Int J Dent. 2011.

2. Manipal S, John J, Saravanan S, Arumugham IM, Kumar P. The effect of different beverages on salivary $\mathrm{pH}$ in 12 years old school children in Chennai. J Orofac Res 2013; 3(3):166-69.

3. Sudeep CB, Jain V, Maliyil M, Sequeira PS, Jain J. Effects on $\mathrm{pH}$ value of saliva following intake of three beverages containing apple juice- a double blind cross over study. Nat J Med Dent Res 2013; 1(4): 18-23.

4. Nikiforuk G. Understanding dental caries, etiology and mechanism, basic clinical aspects. New York. Karger; 1985:pp5o.

5. Johansson I. Milk and dairy products: possible effects on dental health. Scand J Nutrition 2002; 46(3): 119-22.

6. Ravishankar TL, Yadav V, Tangade PS, Tirth A, Chaitra TR. Effect of consuming different dairy products on calcium, phosphorus and $\mathrm{pH}$ levels of human dental plaque: a comparative study. Eur Arch Pediatr Dent 2012; 13(3): 144-8.

7. Ferrazzano GF, Cantile T, Quarto M, Ingenito A, Chianese L, Addeo F. Protective effect of yogurt on dental enamel demineralization in vitro. Australian Dent J 2008; 53: 314-19.
8. Telgi RL, Yadav V, Telgi CR, Boppana N. In vivo dental plaque $\mathrm{pH}$ after consumption of dairy products. Gen Dent 2013: 56-59.

9. Merritt J, Qi F, Shi W. Milk helps build strong teeth and promotes oral health. J Calif Dent Assoc 2006; 34:361-66.

10. Petridou E, Athanassouli T, Panagopoulos H, Revinthi K. Sociodemographic and dietary factors in relation to dental health among Greek adolescents. Community Dent Oral Epidemiol 1996; 24: 307-11.

11. Silva MF, Burgess RC, Sandham HJ, Jenkins GN. Effects of water soluble components of cheese on experimental caries in humans. J Dent Res 1987; 66:3841.

12. Levine RS. Milk, flavoured milk products and caries. Br Dent J 2001; 191-20.

13. Banan LK, Hedge AM. Plaque and salivary $\mathrm{pH}$ changes after consumption of fresh fruit juices. J Clin Pediatr Dent 2005; 30(1): 9-13.

14. Rugg-Gunn AJ, Edgar WM, Geddes DAM. The effect of different meal patterns upon plaque $\mathrm{pH}$ in human subjects. Br Dent J 1975; 139: 351-6.

15. Sliva MF, Jenkins GN, Burgess RC. Effect of cheese on experimental caries in human subjects. Caries Res 1986;20:263-9.

16. Minah GE, McEnery MC, Flores JA. Metabolic differences between saliva from caries active and caries and restoration free children. Arch Oral Biol 1986; 31(10): $633-8$.

17. Rugg-Gunn AJ, Roberts GJ, Wright WG. Effect of human milk on plaque $\mathrm{pH}$ in situ and enamel dissolution in vitro compared with bovine milk, lactose and sucrose. Caries Res 1985; 19(4):327-34.

18. Sonmez IS, Aras S. Effect of white cheese and sugarless yogurt on dental plaque acidogenicity. Caries Res 2007; 41(3): 208-11.

19. Nikawa H, Makihira S, Fukushima $H$. Lactobacillus reuteri in bovine milk fermented decreases the oral carriage of Mutans streptococci. Int J Food Micribial 2004; 95: 219-23.

20. Caglar E, Sandalli N, Twetman S. effect of yogurt with Bifidobacterium DN-173 o10 on salivary mutans streptococci and lactobacilli in young adults. Acta Odontol Scand 2005; 63: 317-20. 
Source of support: Nil, Conflict of interest: None declared

Cite this article as:

Sharma A, Sharma D, Singh S, Sharma A, Sharma R, Sharma M. Milk and Its Products: Effect on Salivary pH. Int Healthcare Res J 2018;2(6):140-145. doi: 10.26440/IHRJ/02_06/198

\section{AUTHOR AFFILIATIONS:}

1. Senior Lecturer, Department Of Pedodontics \& Preventive Dentistry

2. Senior Lecturer, Department Of Oral Medicine and Radiology

Institute of Dental Sciences, Sehora, Jammu, Jammu \& Kashmir, India

3. Senior Lecturer, Department Of Oral Medicine and Radiology, Sri Sukhmani Dental College and Hospital, Derabassi, Punjab, India

4. Senior Lecturer, Department Of Preventive and Community Dentistry

5. Senior Lecturer, Department Of Orthodontics And Dentofacial Orthopedics

6. Senior Lecturer, Department Of Pedodontics \& Preventive Dentistry

Swami Devi Dyal Hospital \& Dental College, Barwala, Haryana, India

\section{*Corresponding Author:}

Dr. Dheeraj Sharma

Department of Oral Medicine and Radiology

Institute of Dental Sciences

Sehora, Jammu

Jammu \& Kashmir

India
For article enquiry/author contact details, e-mail at: manuscriptenquiry.ihrj@gmail.com

\section{LEGENDS}

\begin{tabular}{|c|c|c|c|c|c|}
\hline \multicolumn{2}{|c|}{ Group } & \multicolumn{1}{|c|}{ Baseline } & \multicolumn{2}{c|}{1 minute } & \multicolumn{2}{c|}{ minute } & \multicolumn{1}{c|}{ minute } & \multicolumn{2}{c|}{ minutes } \\
\hline Paneer & $6.50 \pm 0.38$ & $6.76 \pm 0.40$ & $6.86 \pm 0.45$ & $6.75 \pm 0.44$ & $6.63 \pm 0.42$ \\
\hline Milk & $6.61 \pm 0.46$ & $6.60 \pm 0.34$ & $6.38 \pm 0.41$ & $6.54 \pm 0.35$ & $6.64 \pm 0.46$ \\
\hline Curd & $6.63 \pm 0.42$ & $6.17 \pm 0.39$ & $5.55 \pm 0.14$ & $6.12 \pm 0.39$ & $6.54 \pm 0.44$ \\
\hline ANOVA & 0.084 & 10.95 & 57.82 & 11.58 & 0.27 \\
\hline P & $0.632^{\mathrm{c}}$ & $0.000^{\mathrm{a}}$ & $0.000^{\mathrm{a}}$ & $0.000^{\mathrm{a}}$ & $0.765^{\mathrm{c}}$ \\
\hline
\end{tabular}

Table 1. Mean plaque $\mathrm{pH}$ of subjects (+ SD) of different groups at different time intervals. ( $<<0.05$, a: Highly significant; b: Significant; c: Non-significant) 


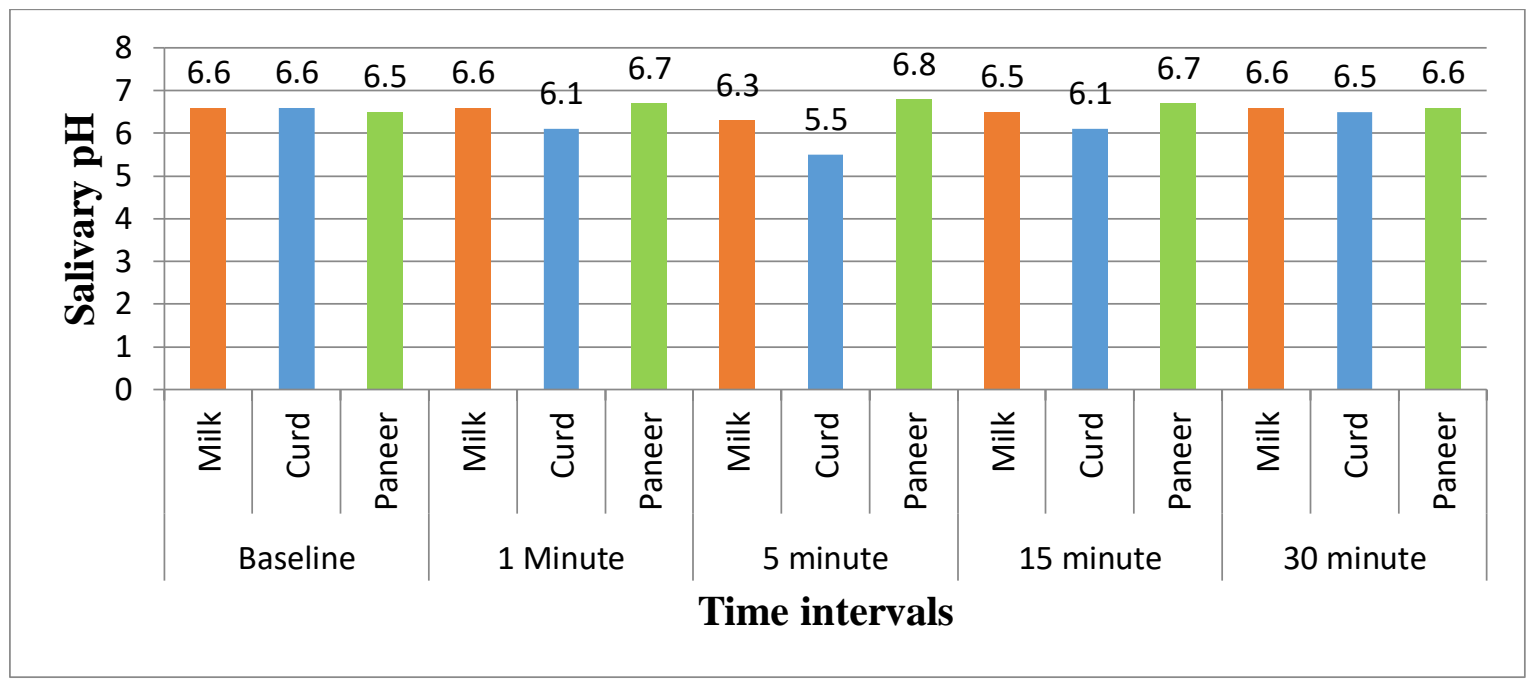

Figure 1. Mean salivary $\mathrm{pH}$ in the three groups at different time intervals

\begin{tabular}{|c|c|c|c|c|c|c|c|c|c|c|}
\hline & \multicolumn{2}{|c|}{ Baseline } & \multicolumn{2}{|c|}{1 minute } & \multicolumn{2}{|c|}{5 minute } & \multicolumn{2}{|c|}{15 minute } & \multicolumn{2}{|c|}{30 minute } \\
\hline Group & Caries & $\begin{array}{c}\text { Caries } \\
\text { free }\end{array}$ & Caries & $\begin{array}{c}\text { Caries } \\
\text { free }\end{array}$ & Caries & $\begin{array}{c}\text { Caries } \\
\text { free }\end{array}$ & Caries & $\begin{array}{l}\text { Caries } \\
\text { free }\end{array}$ & Caries & Caries free \\
\hline Milk & $\begin{array}{c}7.03 \\
\pm 0.14^{\mathrm{a}}\end{array}$ & $\begin{array}{c}6.14 \\
\pm 0.06\end{array}$ & $\begin{array}{c}6.90 \\
+0.15^{\mathrm{a}}\end{array}$ & $\begin{array}{c}6.26 \\
\pm 0.05\end{array}$ & $\begin{array}{c}6.74 \\
\pm 0.14^{\mathrm{a}}\end{array}$ & $\begin{array}{c}5.97 \\
+0.09\end{array}$ & $\begin{array}{c}6.84 \\
+0.18^{a}\end{array}$ & $\begin{array}{c}6.21 \\
+0.04\end{array}$ & $\begin{array}{c}7.06 \\
\pm 0.14^{\mathrm{a}}\end{array}$ & $\begin{array}{c}6.17 \\
+0.04\end{array}$ \\
\hline Curd & $\begin{array}{c}7.01 \\
\pm 0.06^{a}\end{array}$ & $\begin{array}{c}6.20 \\
\pm 0.13\end{array}$ & $\begin{array}{c}6.52 \\
\pm 0.08^{a}\end{array}$ & $\begin{array}{c}5.78 \\
\pm 0.14\end{array}$ & $\begin{array}{c}5.64 \\
\pm 0.10^{b}\end{array}$ & $\begin{array}{r}5.45 \\
\pm 0.12\end{array}$ & $\begin{array}{c}6.47 \\
\pm 0.07^{\mathrm{a}}\end{array}$ & $\begin{array}{c}5.72 \\
\pm 0.13\end{array}$ & $\begin{array}{c}6.94 \\
\pm 0.06^{a}\end{array}$ & $\begin{array}{r}6.09 \\
\pm 0.11\end{array}$ \\
\hline Paneer & $\begin{array}{c}6.80 \\
\pm 0.31^{\mathrm{a}}\end{array}$ & $\begin{array}{c}6.21 \\
\pm 0.11\end{array}$ & $\begin{array}{c}7.07 \\
\pm 0.30^{a}\end{array}$ & $\begin{array}{r}6.45 \\
\pm 0.18\end{array}$ & $\begin{array}{c}7.22 \\
\pm 0.32^{\mathrm{a}}\end{array}$ & $\begin{array}{r}6.50 \\
\pm 0.19\end{array}$ & $\begin{array}{c}7.12 \\
\pm 0.30^{a}\end{array}$ & $\begin{array}{c}6.39 \\
\pm 0.17\end{array}$ & $\begin{array}{c}6.97 \\
\pm 0.31^{\mathrm{a}}\end{array}$ & $\begin{array}{r}6.30 \\
\pm 0.15\end{array}$ \\
\hline
\end{tabular}

Table 2. Mean Saliva pH of subjects (+ SD) at different time intervals among paneer, milk and curd groups. ( $\mathrm{p}<0.05$, a: Highly significant; b: Significant; c: Non-significant) 